\title{
In Memory of Leslie G. Ungerleider
}

\author{
Ning Liu ${ }^{1}$ Hui Zhang ${ }^{2}$ Xilin Zhang ${ }^{3,4} \cdot$ Jiongjiong Yang ${ }^{5}$ Xuchu Weng ${ }^{3,6}$. \\ Lin Chen ${ }^{1,7}$
}

Received: 5 January 2021 / Accepted: 12 January 2021/Published online: 6 March 2021

(c) Center for Excellence in Brain Science and Intelligence Technology, CAS 2021

Dr. Leslie Ungerleider, who together with Mortimer Mishkin established the model of "two functionally dissociated cortical visual pathways in the primate brain" [1], passed away on December 11, 2020. Ungerleider's model of two visual pathways is one of the most profound and influential theories in contemporary neuroscience. In addition, Leslie's impact on the Chinese cognitive neuroscience community [2] is so strong that we feel moved to write this essay to memorize her, our beloved colleague and mentor. We hope her scientific heritage will continue to inspire us and give impetus to our scientific efforts to develop cognitive neuroscience in China.

Leslie was an elected member of the National Academy of Sciences (2000), the American Academy of Arts and Sciences (2000), and the Institute of Medicine of the

Ning Liu

ningliu.brain@gmail.com

1 State Key Laboratory of Brain and Cognitive Science, Institute of Biophysics, Chinese Academy of Sciences, Beijing 100101, China

2 Beijing Advanced Innovation Center for Big Data-Based Precision Medicine, School of Medicine and Engineering, Beihang University, Beijing 100191, China

3 Key Laboratory of Brain, Cognition and Education Sciences, Ministry of Education, South China Normal University, Guangzhou 510631, Guangdong, China

4 School of Psychology, South China Normal University, Guangzhou 510631, Guangdong, China

5 School of Psychological and Cognitive Sciences, Peking University, Beijing 100871, China

6 Institute for Brain Research and Rehabilitation, South China Normal University, Guangzhou 510631, Guangdong, China

7 University of Chinese Academy of Sciences, Beijing 100049, China
National Academy of Sciences (2001), a rare triple-play in science. Leslie won nearly every honor in the field of cognitive neuroscience and psychological science, including the Women in Neuroscience Lifetime Achievement Award (2001), the George A. Miller Award (2005), the William James Fellow Award (2010), the Grawemeyer Award (2012), the Andrew Carnegie Prize (2013), and the Glass Brain Award (2020).

Leslie grew up in New York City. She earned her bachelor's degree at the State University of New York at Binghamton. Then she got her doctorate with Edgar Coons at New York University, where Leslie published her first paper, which was in Science [3]. In 1972, she became a Postdoc at Stanford University and began her research in non-human primates. In 1975, she moved to the National Institute of Mental Health and worked with Mortimer Mishkin in the Laboratory of Neuropsychology. In 1995, she established her own laboratory, the Laboratory for Brain and Cognition, where she remained for the rest of her career. In 2008, Leslie became an NIH Distinguished Investigator.

Leslie was an immensely influential functional anatomist. She conducted a series of investigations studying the cortical and subcortical projections of visual areas (e.g., V4, MT, TEO, and IT) in the macaque [4-19]. Moreover, her studies based on behavioral assessments of selective brain lesions in macaques made outstanding achievements in relating neuroanatomy to behavior [20-36]. Most notably, her research with Mortimer led to one of her best-known discoveries: two cortical visual systems in primates-a ventral pathway projecting from the striate cortex into the temporal cortex, specializing in object recognition (the "what" stream), and a dorsal pathway projecting from the striate cortex into the parietal cortex, specializing in visuospatial perception (the "where" 
stream) [1]. This pivotal work continues to be one of the most impactful and influential concepts in visual neuroscience and has guided numerous subsequent studies in non-human primates as well as in humans. Later in her career, Leslie and her colleagues have expanded the twovisual pathway model. They proposed that the ventral visual pathway is a recurrent network that provides visual information to at least six distinct cortical and subcortical areas, each mediating different forms of learning and memory [37]. Recently, Leslie and her colleagues proposed that there is a third visual pathway on the lateral brain surface specializing in higher sociocognitive functions based on dynamic social cues (e.g., moving faces and bodies) [38]. Together, these studies have provided us a broader, systems-level picture of the primate visual system.

Leslie was also an enormously talented experimental physiologist and cognitive neuroscientist. Over years, she made a significant cumulative contribution to understanding the neural mechanisms underlying cognitive processes, including perception, memory, attention, emotion, and decision-making, especially in the visual modality (for reviews, see [39-44]).

Throughout her entire career, Leslie was a pioneer in combining cutting-edge technologies with classical approaches. She was keenly aware of the importance of neuroimaging techniques (e.g., positron emission tomography and magnetic resonance imaging [fMRI]) for understanding the structure-function relationships of brain regions at the macroscopic level $[45,46]$. By combining fMRI with effective connectivity analysis, Leslie and her colleagues systematically revealed the neural mechanisms of attention [47-50]. In recent years, Leslie combined fMRI with anatomical tracing techniques, interventional physiology, pharmacological manipulation, and electrophysiological recording to investigate the brain in a comprehensive way. By this multidisciplinary approach, Leslie and her colleagues greatly expanded our knowledge of the functional architecture and properties of visual cortices [51-58]. Moreover, her parallel fMRI studies conducted in humans and non-human primates tested the generality of this knowledge across species [59-61].

Leslie was a warm colleague and mentor for many Chinese scholars and students. She visited China multiple times. In April 2004, Leslie was invited to give a keynote speech at the 3rd International Symposium on Cognitive Neuroscience in Hong Kong. A few months later, invited by Lin Chen, Leslie visited Beijing in October and gave a talk entitled "How the Brain Pays Attention". In June 2012, Leslie visited Beijing for the second time and gave a talk entitled "Functional Architecture of Face Processing in the Primate Brain" at the Organization for Human Brain Mapping Annual Meeting. Over the years, Leslie had built up an international network of collaborators including many researchers from China. Leslie also mentored a steady stream of young Chinese researchers, many of whom have come back to China as independent scientists. As shown below, they will eternally cherish the memory of Leslie, their beloved mentor and colleague.

"Leslie was a wonderful scientist and mentor. I learned from her how to think and work more critically. She taught me that solid work is the only thing that eventually matters. Leslie knew the difficulties that young scientists might meet, especially women scientists. So, she always tried her best to help us. Because she was there, I felt supported and found the courage to face difficulties and move forward. Everything I learned from her made me continue my career in science. She will always be there, in our memories, in our knowledge, and the skills that we learned from her." Ning Liu (Institute of Biophysics, Chinese Academy of Sciences), a Postdoc with Leslie.

"As a scientist, Leslie's groundbreaking work on the 'two cortical visual systems' has revolutionized the way we think about the functional architecture of the brain and has been immensely influential on generations of brain scientists. As a mentor, Leslie was very patient, warm, generous, inspired, and supportive-she always tried her best to help us in many aspects. Knowing her support was there and always available if I ever needed it was so important to me to set up my own lab and continue my career in science. As a leader, Leslie was straightforward but compassionate. Everyone was cared for deeply and equally by her excellent leadership. Leslie is a giant of cognitive neuroscience, vision science, and psychology and will live on in our memories and textbooks."-Xilin Zhang (School of Psychology, South China Normal University), a Postdoc with Leslie.

"As a giant in the field of neuroscience, Leslie's many research studies have not only profoundly influenced researchers in the fields of neuroscience, psychology, vision, and brain science, but have also inspired researchers in the new fields of computer science and artificial intelligence. As a wonderful mentor, she was always there, giving young researchers, including Chinese scholars like me, generous support and help. It is because of her encouragement and support that I have enough confidence and courage to face all the challenges of pursuing my science career."-Hui Zhang (School of Medicine and Engineering, Beihang University), a Postdoc with Leslie.

"Leslie is one of most respected scientists I have ever met. I still remember the days when we listened to her insightful comments on papers and studies in lab meetings. She profoundly influenced many of us young investigators on how to think about the world in a scientific way. I also remember the wonderful moments when I discussed our studies with her. She was always warm, kind, and supportive to everybody in the lab. Leslie's excellent work 
is a milestone in cognitive neuroscience, and her encouragement inspires me to continue pursuits in this field"Jiongjiong Yang (School of Psychological and Cognitive Sciences, Peking University), a visiting fellow with Alex Martin in the joint Lab of Brain and Cognition with Leslie.

\section{References}

1. Underleider LG, Mishkin M. Two cortical visual systems. In: Ingle MA, Ingle MA, Goodale MI, Masfield RJW, editors. Analysis of Visual Behavior. Cambridge, MA: MIT Press; 1982, 549-586.

2. Zhuo Y, Zhou TG, Rao HY, Wang JJ, Meng M, Chen M, et al. Contributions of the visual ventral pathway to long-range apparent motion. Science 2003, 299: 417-420.

3. Ungerleider LG, Coons EE. A behavioral measure of homosynaptic and heterosynaptic temporal summation in the selfstimulation system of rats. Science 1970, 169: 785-787.

4. Adams MM, Hof PR, Gattass R, Webster MJ, Ungerleider LG. Visual cortical projections and chemoarchitecture of macaque monkey pulvinar. J Comp Neurol 2000, 419: 377-393.

5. Boussaoud D, Desimone R, Ungerleider LG. Visual topography of area TEO in the macaque. J Comp Neurol 1991, 306: 554-575.

6. Boussaoud D, Ungerleider LG, Desimone R. Pathways for motion analysis: cortical connections of the medial superior temporal and fundus of the superior temporal visual areas in the macaque. J Comp Neurol 1990, 296: 462-495.

7. Desimone R, Ungerleider LG. Multiple visual areas in the caudal superior temporal sulcus of the macaque. J Comp Neurol 1986, 248: 164-189.

8. Distler C, Boussaoud D, Desimone R, Ungerleider LG. Cortical connections of inferior temporal area TEO in macaque monkeys. J Comp Neurol 1993, 334: 125-150.

9. Farias MF, Gattass R, Pinon MC, Ungerleider LG. Tangential distribution of cytochrome oxidase-rich blobs in the primary visual cortex of macaque monkeys. J Comp Neurol 1997, 386: 217-228.

10. Gattass R, Galkin TW, Desimone R, Ungerleider LG. Subcortical connections of area V4 in the macaque. J Comp Neurol 2014, 522: 1941-1965.

11. Hof PR, Ungerleider LG, Webster MJ, Gattass R, Adams MM, Sailstad CA, et al. Neurofilament protein is differentially distributed in subpopulations of corticocortical projection neurons in the macaque monkey visual pathways. J Comp Neurol 1996, 376: 112-127.

12. Saint-Cyr JA, Ungerleider LG, Desimone R. Organization of visual cortical inputs to the striatum and subsequent outputs to the pallido-nigral complex in the monkey. J Comp Neurol 1990, 298: 129-156.

13. Ungerleider LG, Desimone R. Cortical connections of visual area MT in the macaque. J Comp Neurol 1986, 248: 190-222.

14. Ungerleider LG, Desimone R. Projections to the superior temporal sulcus from the central and peripheral field representations of V1 and V2. J Comp Neurol 1986, 248: 147-163.

15. Ungerleider LG, Desimone R, Galkin TW, Mishkin M. Subcortical projections of area MT in the macaque. J Comp Neurol 1984, 223: 368-386.

16. Ungerleider LG, Galkin TW, Mishkin M. Visuotopic organization of projections from striate cortex to inferior and lateral pulvinar in rhesus monkey. J Comp Neurol 1983, 217: 137-157.
17. Ungerleider LG, Mishkin M. The striate projection zone in the superior temporal sulcus of Macaca mulatta: location and topographic organization. J Comp Neurol 1979, 188: 347-366.

18. Webster MJ, Bachevalier J, Ungerleider LG. Subcortical connections of inferior temporal areas TE and TEO in macaque monkeys. J Comp Neurol 1993, 335: 73-91.

19. Webster MJ, Bachevalier J, Ungerleider LG. Transient subcortical connections of inferior temporal areas TE and TEO in infant macaque monkeys. J Comp Neurol 1995, 352: 213-226.

20. Mishkin M, Lewis ME, Ungerleider LG. Equivalence of parietopreoccipital subareas for visuospatial ability in monkeys. Behav Brain Res 1982, 6: 41-55.

21. Mishkin M, Ungerleider LG. Contribution of striate inputs to the visuospatial functions of parieto-preoccipital cortex in monkeys. Behav Brain Res 1982, 6: 57-77.

22. Ungerleider LG, Christensen CA. Pulvinar lesions in monkeys produce abnormal eye movements during visual discrimination training. Brain Res 1977, 136: 189-196.

23. Ungerleider LG, Pribram KH. Inferotemporal versus combined pulvinar-prestriate lesions in the rhesus monkey: effects on color, object and pattern discrimination. Neuropsychologia 1977, 15: 481-498.

24. Ungerleider LG, Christensen CA. Pulvinar lesions in monkeys produce abnormal scanning of a complex visual array. Neuropsychologia 1979, 17: 493-501.

25. Webster MJ, Ungerleider LG, Bachevalier J. Lesions of inferior temporal area TE in infant monkeys alter cortico-amygdalar projections. Neuroreport 1991, 2: 769-772.

26. De Weerd P, Desimone R, Ungerleider LG. Cue-dependent deficits in grating orientation discrimination after V4 lesions in macaques. Vis Neurosci 1996, 13: 529-538.

27. De Weerd P, Peralta MR 3rd, Desimone R, Ungerleider LG. Loss of attentional stimulus selection after extrastriate cortical lesions in macaques. Nat Neurosci 1999, 2: 753-758.

28. De Weerd P, Desimone R, Ungerleider LG. Impairments in spatial generalization of visual skills after V4 and TEO lesions in macaques (Macaca mulatta). Behav Neurosci 2003, 117: 1441-1447.

29. De Weerd P, Desimone R, Ungerleider LG. Generalized deficits in visual selective attention after V4 and TEO lesions in macaques. Eur J Neurosci 2003, 18: 1671-1691.

30. Bertini G, Buffalo EA, De Weerd P, Desimone R, Ungerleider LG. Visual responses to targets and distracters by inferior temporal neurons after lesions of extrastriate areas V4 and TEO. Neuroreport 2004, 15: 1611-1615.

31. Buffalo EA, Bertini G, Ungerleider LG, Desimone R. Impaired filtering of distracter stimuli by TE neurons following V4 and TEO lesions in macaques. Cereb Cortex 2005, 15: 141-151.

32. Rossi AF, Bichot NP, Desimone R, Ungerleider LG. Top down attentional deficits in macaques with lesions of lateral prefrontal cortex. J Neurosci 2007, 27: 11306-11314.

33. Hadj-Bouziane F, Liu N, Bell AH, Gothard KM, Luh WM, Tootell RB, et al. Amygdala lesions disrupt modulation of functional MRI activity evoked by facial expression in the monkey inferior temporal cortex. Proc Natl Acad Sci U S A 2012, 109: E3640-3648.

34. Gregoriou GG, Rossi AF, Ungerleider LG, Desimone R. Lesions of prefrontal cortex reduce attentional modulation of neuronal responses and synchrony in V4. Nat Neurosci 2014, 17: 1003-1011.

35. Taubert J, Flessert M, Wardle SG, Basile BM, Murphy AP, Murray EA, et al. Amygdala lesions eliminate viewing preferences for faces in rhesus monkeys. Proc Natl Acad Sci U S A 2018, 115: 8043-8048.

36. Farias MF, Ungerleider LG, Pereira SS, Amorim AKJ, Soares JGM, Gattass R. Time course of cytochrome oxidase blob 
plasticity in the primary visual cortex of adult monkeys after retinal laser lesions. J Comp Neurol 2019, 527: 600-613.

37. Kravitz DJ, Saleem KS, Baker CI, Ungerleider LG, Mishkin M. The ventral visual pathway: an expanded neural framework for the processing of object quality. Trends Cogn Sci 2013, 17: 26-49.

38. Pitcher D, Ungerleider LG. Evidence for a Third Visual Pathway Specialized for Social Perception. Trends Cogn Sci 2020.

39. Kastner S, Ungerleider LG. Mechanisms of visual attention in the human cortex. Annu Rev Neurosci 2000, 23: 315-341.

40. Heekeren HR, Marrett S, Ungerleider LG. The neural systems that mediate human perceptual decision making. Nat Rev Neurosci 2008, 9: 467-479.

41. Pessoa L, Ungerleider LG. Neuroimaging studies of attention and the processing of emotion-laden stimuli. Prog Brain Res 2004, 144: $171-182$.

42. Ungerleider LG. Functional brain imaging studies of cortical mechanisms for memory. Science 1995, 270: 769-775.

43. Ungerleider LG, Courtney SM, Haxby JV. A neural system for human visual working memory. Proc Natl Acad Sci U S A 1998, 95: 883-890.

44. Ungerleider LG, Bell AH. Uncovering the visual "alphabet": advances in our understanding of object perception. Vision Res 2011, 51: 782-799.

45. Ungerleider LG, Haxby JV. "What" and "where" in the human brain. Curr Opin Neurobiol 1994, 4: 157-165.

46. Courtney SM, Ungerleider LG. What fMRI has taught us about human vision. Curr Opin Neurobiol 1997, 7: 554-561.

47. Huang L, Wang L, Shen W, Li M, Wang S, Wang X, et al. A source for awareness-dependent figure-ground segregation in human prefrontal cortex. Proc Natl Acad Sci U S A 2020, 117: 30836-30847.

48. Zhang X, Mlynaryk N, Ahmed S, Japee S, Ungerleider LG. The role of inferior frontal junction in controlling the spatially global effect of feature-based attention in human visual areas. PLoS Biol 2018, 16: e2005399.

49. Zhang X, Mlynaryk N, Japee S, Ungerleider LG. Attentional selection of multiple objects in the human visual system. Neuroimage 2017, 163: 231-243.

50. Zhang X, Japee S, Safiullah Z, Mlynaryk N, Ungerleider LG. A Normalization Framework for Emotional Attention. PLoS Biol 2016, 14: e1002578.
51. Hadj-Bouziane F, Bell AH, Knusten TA, Ungerleider LG, Tootell RB. Perception of emotional expressions is independent of face selectivity in monkey inferior temporal cortex. Proc Natl Acad Sci U S A 2008, 105: 5591-5596.

52. Bell AH, Malecek NJ, Morin EL, Hadj-Bouziane F, Tootell RB, Ungerleider LG. Relationship between functional magnetic resonance imaging-identified regions and neuronal category selectivity. J Neurosci 2011, 31: 12229-12240.

53. Liu N, Kriegeskorte N, Mur M, Hadj-Bouziane F, Luh WM, Tootell RB, et al. Intrinsic structure of visual exemplar and category representations in macaque brain. J Neurosci 2013, 33: 11346-11360.

54. Liu N, Hadj-Bouziane F, Jones KB, Turchi JN, Averbeck BB, Ungerleider LG. Oxytocin modulates fMRI responses to facial expression in macaques. Proc Natl Acad Sci U S A 2015, 112: E3123-3130.

55. Liu N, Hadj-Bouziane F, Moran R, Ungerleider LG, Ishai A. Facial Expressions Evoke Differential Neural Coupling in Macaques. Cereb Cortex 2017, 27: 1524-1531.

56. Taubert J, Japee S, Murphy AP, Tardiff CT, Koele EA, Kumar S, et al. Parallel Processing of Facial Expression and Head Orientation in the Macaque Brain. J Neurosci 2020, 40: 8119-8131.

57. Furl N, Hadj-Bouziane F, Liu N, Averbeck BB, Ungerleider LG. Dynamic and static facial expressions decoded from motionsensitive areas in the macaque monkey. J Neurosci 2012, 32: 15952-15962.

58. Yue X, Pourladian IS, Tootell RB, Ungerleider LG. Curvatureprocessing network in macaque visual cortex. Proc Natl Acad Sci U S A 2014, 111: E3467-3475.

59. Bell AH, Hadj-Bouziane F, Frihauf JB, Tootell RB, Ungerleider LG. Object representations in the temporal cortex of monkeys and humans as revealed by functional magnetic resonance imaging. J Neurophysiol 2009, 101: 688-700.

60. Zhang H, Japee S, Stacy A, Flessert M, Ungerleider LG. Anterior superior temporal sulcus is specialized for non-rigid facial motion in both monkeys and humans. Neuroimage 2020, 218: 116878.

61. Nasr S, Liu N, Devaney KJ, Yue X, Rajimehr R, Ungerleider LG, et al. Scene-selective scortical regions in human and nonhuman primates. J Neurosci 2011, 31: 13771-13785. 